\title{
Pengaruh Waktu Pembebanan Dan Kecepatan Terhadap Keausan Paduan Tembaga (Cu) Dan Karbon (C)
}

\author{
Tri Surawan ${ }^{1)}$ dan Didik Mulyadi ${ }^{2)}$ \\ 1) Jurusan Teknik Mesin, Fakultas Teknik Industri, Universitas Jayabaya \\ Jl. Raya Bogor Km. 28,8 Cimanggis, Jakarta Timur / Telp. (021) 8714823, 8722485. \\ 2) Jurusan Teknik Mesin, Fakultas Teknik, Universitas Pancasila \\ Jl. Srengseng Sawah, Jagakarsa, Jakarta 12640/ Telp. (021) 7864730 Ext.101 / Fax.(021) 7270128, 7272290. \\ Corresponding author: tri.surawan@gmail.com
}

\begin{abstract}
The problem that often occurs in the world of railways is how to reduce the loss due to wear and tear. The most common wear and tear is the material with a low level of hardness. Some factors that affect the wear and tear on a material are speed, pressure, surface roughness and material hardness. Contact strip is one component that often experience wear and tear. This research is used an experimental method with the objective to know the wear rate of contact strip. In this study using independent variables with variations of speed 500, 900, 1250, 2100 rpm and variations of test time 1, 2, 3, 4, 5 minutes. In this study sliding speed and times variate respectively in 500, 900, 1250, and 2100 rpm for 1, 2, 3, 4, and 5 minutes. Wear rate of $C$ contact strip increasing with increasing the sliding speed and times. How every the wear rate of $C$ contact strip is slow as comparate to the wear rate of $\mathrm{Cu}$ contact strip. After tested, the hardness values of trolley wire is 42,0 HRB, contact strip of $\mathrm{Cu}$ is 40,8 HRB and while contact strip C is 38,7 HRB. The highest specific wear and tear rate was found on contact strip of $C$ with $0,01558 \mathrm{~mm} 3 / \mathrm{Nm}$ and the lowest wear rate was found on $\mathrm{Cu}$ contact strip of 0,00398 mm3/Nm. The wear test results show that the wear rate will increase along with increasing the sliding.
\end{abstract}

\begin{abstract}
Abstrak
Permasalahan yang sering terjadi pada dunia perkeretaapian adalah bagaimana cara menekan kerugian akibat keausan. Keausan yang paling sering terjadi adalah pada material yang tingkat kekerasannya rendah. Beberapa faktor yang mempengaruhi keausan pada suatu material adalah kecepatan, tekanan, kekasaran permukaan dan kekerasan material. Contact strip merupakan salah satu komponen yang sering mengalami keausan. Metode penelitian yang digunakan dalam penelitian ini adalah metode eksperimental dengan tujuan untuk mengetahui laju keausan contact strip. Dalam penelitian ini kecepatan putar dan waktu bervariasi yaitu pada 500, 900, 1250, dan $2100 \mathrm{rpm}$ dalam 1, 2, 3, 4, dan 5 menit. Tingkat keausan contact strip $\mathrm{C}$ meningkat seiring dengan meningkatnya kecepatan dan waktu. Dimana tingkat keausan contact strip $\mathrm{C}$ lebih bila dibandingkan dengan tingkat keausan contact strip $\mathrm{Cu}$. Setelah diuji maka didapatkan nilai kekerasan dari masing - masing spesimen adalah trolley wire sebesar 42,0 HRB, contact strip Cu sebesar 40,8 HRB dan contact strip C, dan contact strip C sebesar 38,7 HRB. Nilai laju keausan spesifik terbesar terdapat pada contact strip C dengan nilai $0,01558 \mathrm{~mm}^{3} / \mathrm{Nm}$ dan nilai laju keausan terendah terdapat pada contact strip $\mathrm{Cu}$ yaitu sebesar 0,00398 $\mathrm{mm}^{3} / \mathrm{Nm}$. Hasil pengujian keausan menunjukan bahwa laju keausan akan semakin meningkat seiring dengan perubahan variabel bebas pada proses pengujian.
\end{abstract}

Keywords: Contact Strip, Trolley Wire, Wear and Tear Rate 
Jurnal Teknologi, Tahun 2019, Volume 6, Edisi 2

\section{PENDAHULUAN}

Pantograph merupakan unit komponen yang digunakan pada Kereta Rel Listrik (KRL) sebagai penghubung dari listrik aliran atas ke KRL. Komponen utama yang terdapat pada pantograph dan mempunyai peranan penting yaitu contact strip, karena berhubungan langsung dengan jaringan listrik aliran atas. Komponen tersebut mempunyai usia pakai yang relatif singkat dalam jumlah perjalanan KRL yang sangat padat.

Permasalahan yang sering terjadi pada alat transportasi darat khususnya KRL adalah bagaimana cara menekan kerugian yang disebabkan oleh ausnya pada salah satu komponennya. Keausan sering terjadi pada material yang mempunyai tingkat kekerasannya rendah. Ada beberapa faktor yang mempengaruhi keausan pada suatu material yaitu kekerasan, tekanan, kekasaran permukaan serta kecepatan. Contact strip merupakan salah satu komponen yang sering mengalami keausan [1]. Berdasarkan data di lapangan contact strip mengalami penurunan ketebalan rata-rata sebesar $3-4 \mathrm{~mm}$ dalam kurun waktu tiga bulan dengan batas aus yang diijinkan $4 \mathrm{~mm}$.

C.T. Kwok (2010) melakukan penelitian tentang laju keausan pada enam paduan tembaga berkekuatan komersial pada $\mathrm{CuCr}$ (C18200), CuZr (C15000), CuCrZr (C18150), CuNiSiCr (C18000), $\mathrm{CuBe}(\mathrm{C} 17200)$ \& $\mathrm{CuBeNi}(\mathrm{C} 17510)$ dan $\mathrm{Cu}$ yang ditarik dengan keras (C11000). Dimensi pin yang digunakan berdiameter $13 \mathrm{~mm}$ dan panjang $13 \mathrm{~mm}$. Uji kekerasan dilakukan dengan menggunakan mikro tester pada beban $1 \mathrm{~kg}$ dengan waktu pengujian 10 detik. Uji keausan paduan dilakukan dengan menggunakan tribometer pin-on-disc [2].

Tao Ding (2014) melakukan penelitian tentang keausan terhadap contact strip Karbon (C) dengan menggunakan tribometer ring-on-block. Putaran disc digerakkan oleh motor $58 \mathrm{KW}$ dengan frekuensi variabel kecepatan putar antara $0-40 \mathrm{~km} / \mathrm{jam}$. Dudukan contact strip didorong oleh motor servo dengan gaya normal antara contac strip dan trolley wire. Dan gaya yang diberikan bervariasi yaitu 10 sampai dengan $300 \mathrm{~N}$. Dalam pengujian gaya yang diberikan adalah 30, 90, dan 150 N. Dengan intensitas arus listrik 0, 180, 200, 220, dan 240 A. Kecepatan putaran ring diatur pada putaran $160 \mathrm{~km} / \mathrm{jam}$ dan jarak sliding pada masing masing pengetesan diatur pada $200 \mathrm{~km}$. Sebelum pengujian contact strip di poles menggunakan kertas abrasive dengan grit 1000 dan 1200, kemudian dibersihkan dengan menggunakan alkohol [3].

GX Chen (2017) melakukan penelitian contact strip dengan menggunakan adalah jenis tester yang terdiri dari disc rotasi, dudukan contact strip, rangka kontruksi, dan motor frekuensi variabel tribometer block-on-ring. Contact strip dipasang pada sisi disc rotasi. Disc berdiameter $1100 \mathrm{~mm}$ digerakan dengan menggunakan motor frekuensi variabel. Contact strip dengan dengan panjang $130 \mathrm{~mm}$ dipasang pada dudukan contact strip yang memiliki luas penampang melintang terhadap kontak yang digunakan pada kereta listrik [4].

\section{LANDASAN TEORI}

KRL atau Kereta Rel Listrik adalah kereta atau sarana gerak yang menggunakan energi listrik sebagai sumber daya penggeraknya, yang artinya dalam operasi normal KRL bersifat mandiri tidak memerlukan lokomotif penarik sebagai penggeraknya. Sementara untuk sumber catu daya listriknya tersedia melalui kawat aliran atas (trolley wire) bertegangan 1500 VDC yang disuplai melalui gardu-gardu listrik sepanjang lintasan KRL.

Fungsi terpenting dari pantograph adalah sebagai pengumpul arus yang dibutuhkan kereta rel listrik secara terus menerus. Untuk itu pantograph harus memiliki konduktivitas dan kapasitas yang sesuai dalam penggunaanya, sehingga tidak mudah rusak pada saat kereta rel listrik melaju dengan kecepatan tinggi. 
Faktor-faktor yang menentukan kolektivitas pantograph pada kereta rel listrik terbagi menjadi dua faktor yaitu: kinerja dinamis pantograph dan ketahanan aus antara contact strip dan kawat aliran atas.

Keausan didefinisikan sebagai kehilangan material secara progresif atau pemindahan sejumlah material dari suatu permukaan dari suatu hasil pergerakan relatif antara permukaan tersebut dan permukaan lainnya. Keausan telah menjadi perhatian praktis sejak lama, tetapi hingga beberapa saat lamanya masih belum mendapatkan penjelasan sebagaimana halnya pada mekanisme kerusakan akibat pembebanan yang berkaitan dengan gesekan (friction) dari permukaan material. Pembahasan mekanisme keausan pada material ini yang dikenal dengan nama ilmu Tribologi. Keausan bukan merupakan sifat dasar material, melainkan respon material terhadap sistem luar (kontak permukaan).

Material apapun dapat mengalami keausan disebabkan mekanisme yang beragam, yaitu [17]:

\section{a. Keausan adhesive}

Terjadi bila kontak permukaan dari dua material atau lebih mengakibatkan adanya perlekatan satu sama lain dan pada akhirnya terjadi pelepasan salah satu material, seperti terlihat pada Gambar 1.

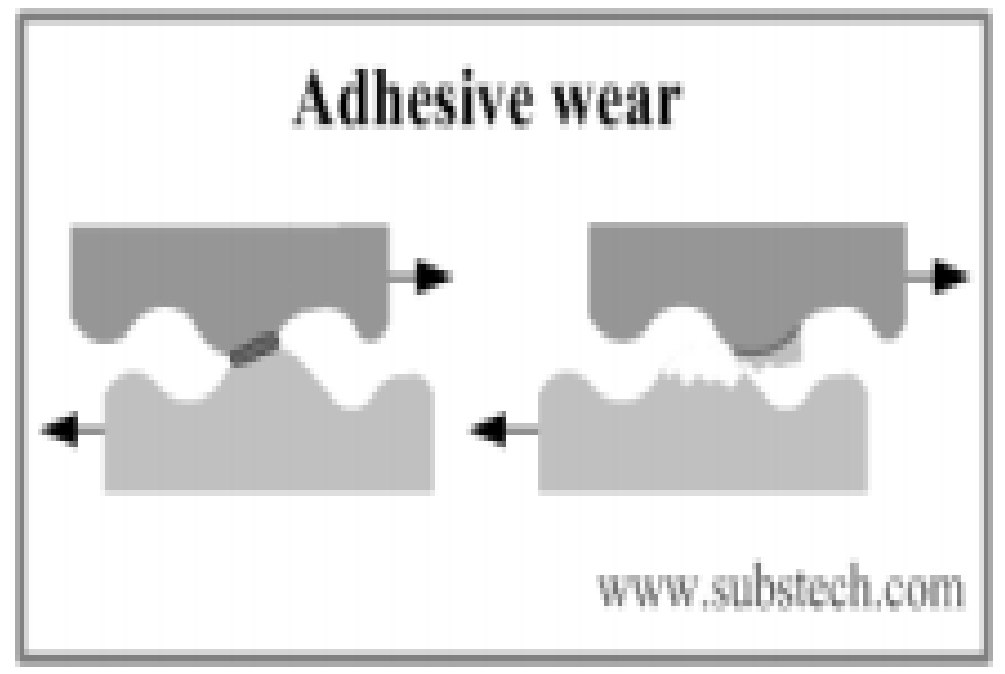

Gambar 1. Ilustrasi skematis keausan adhesive

\section{b. Keausan abrasive}

Terjadi bila suatu partikel keras dari material tertentu meluncur pada permukaan material lain yang lebih lunak sehingga terjadi penetrasi atau pemotongan material yang lebih lunak, sebagaimana ditunjukkan pada Gambar 2. 


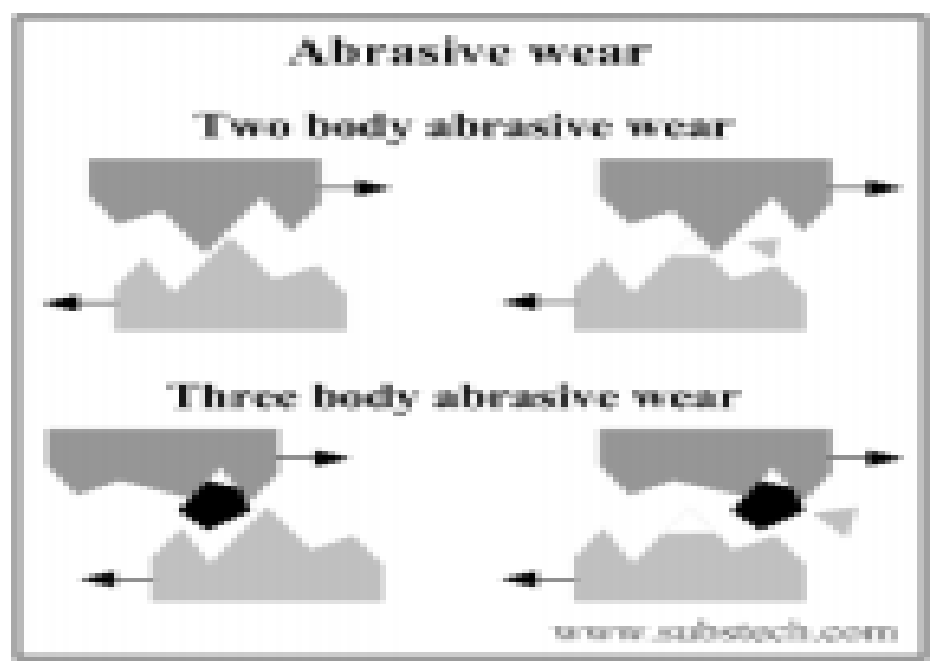

Gambar 2. Ilustrasi skematis keausan abrasive

\section{c. Keausan lelah}

Merupakan mekanisme yang relatif berbeda dibandingkan dua mekanisme sebelumnya, yaitu dalam hal interaksi permukaan. Baik keausan adhesive maupun abrasive. Hanya satu interaksi sementara pada keausan lelah dibutuhkan interaksi multi. Gambar 3 memberikan skematis mekanisme keausan lelah.

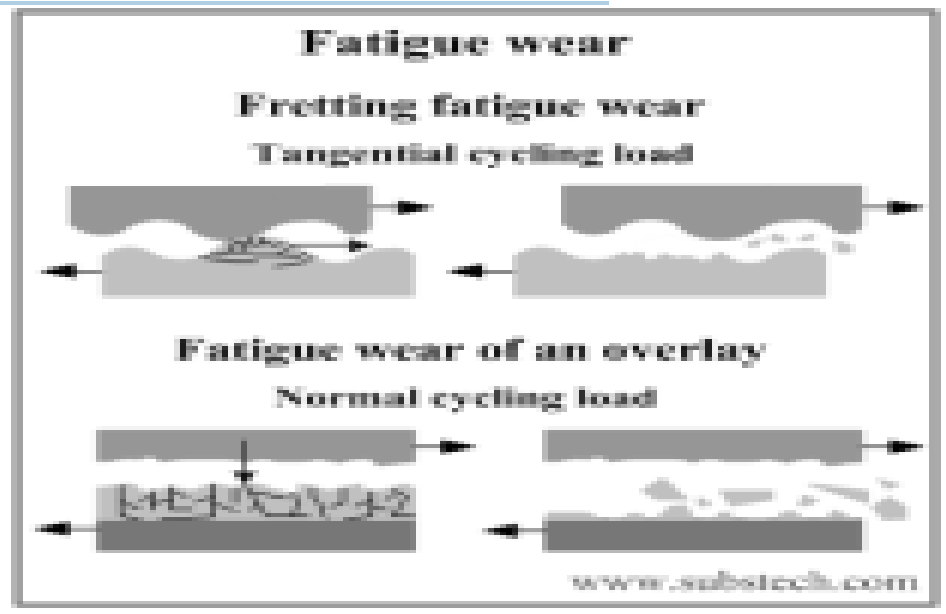

Gambar 3. Ilustrasi skematis keausan lelah

Untuk menentukan laju keausan pada contact strip dapat dihitung dengan menggunakan persamaan sebagai berikut :

$$
\Delta m=M_{O}-M_{A}
$$

Dengan perubahan $\Delta \mathrm{m}$ dibagi massa jenis $\rho$ adalah perubahan volume $\Delta \mathrm{V}$, sehingga persamaan dapat dituliskan sebagai berikut :

$$
\Delta V m m^{3}=\frac{\Delta m}{\rho}
$$

Dengan demikian maka nilai specific wear rate pada contact strip $\mathrm{Cu}$ dan $\mathrm{C}$ dapat diketahui dengan persamaan sebagai berikut: 
Jurnal Teknologi, Tahun 2019, Volume 6, Edisi 2

$$
K=\frac{\Delta V}{F . L}
$$

Dimana :

$\Delta \mathrm{m}=$ Perubahan massa $(\mathrm{gr})$

$\mathrm{M}_{\mathrm{O}}=$ Berat awal spesimen $(\mathrm{gr})$

$\mathrm{M}_{\mathrm{A}}=$ Berat akhir spesimen (gr)

$\Delta \mathrm{V}=$ Perubahan volume $\left(\mathrm{mm}^{3}\right)$

$\rho=$ Massa jenis spesimen $\left(\mathrm{gr} / \mathrm{mm}^{3}\right)$

$\mathrm{F}=$ Beban $(\mathrm{N})$

$\mathrm{L}=$ Panjang lintasan $(\mathrm{m})$

$\mathrm{K}=$ Specific wear rate $\left(\mathrm{mm}^{3} / \mathrm{Nm}\right)$

\section{METODOLOGI}

Metode penelitian yang digunakan dalam penelitian ini adalah metode eksperimental dengan tujuan untuk mengetahui laju keausan contact strip. Pada penelitian ini dilakukan melalui beberapa tahapan sebagai study exsperimental. Awalnya melakukan persiapan spesimen, yaitu membuat pin yang terbuat dari contact strip dengan material karbon dan tembaga, mencari nilai kekerasan dari setiap spesimen, melakukan pemotongan pada spesimen, dan disc menggunakan polishing pad yang dilapisi kertas abrasif sebagai media gesek. Penelitian ini dilakukan dengan menggunakan mesin bor mengacu pada tribologi pinon-disc. Pin dicekam pada ragum, polishing pad sebagai disc dipasang pada chuck. Hidupkan mesin bor kemudian tekan tuas pada mesin bor sesuai dengan beban yang sudah ditentukan. Pada penelitian ini terdapat beberapa variabel yaitu variasi kecepatan pada 500, 900, 1250, dan $2100 \mathrm{rpm}$, variasi waktu pengujian 1, 2, 3, 4, dan 5 menit, dengan beban konstan 0,143 N. Panjang lintasan 0,314 m dan jarak tempuh disesuaikan dengan rpm pada saat pengujian. Keausan dilihat dari perubahan massa yang terjadi pada spesimen sebelum dan sesudah pengujian. Setelah dilakukan pengujian permukaan pin akan di foto mikro untuk mengetahui mekanisme keausan yang terjadi. Alat tribometer yang digunakan dalam penelitian ini dapat dilihat pada Gambar 4 berikut ini.

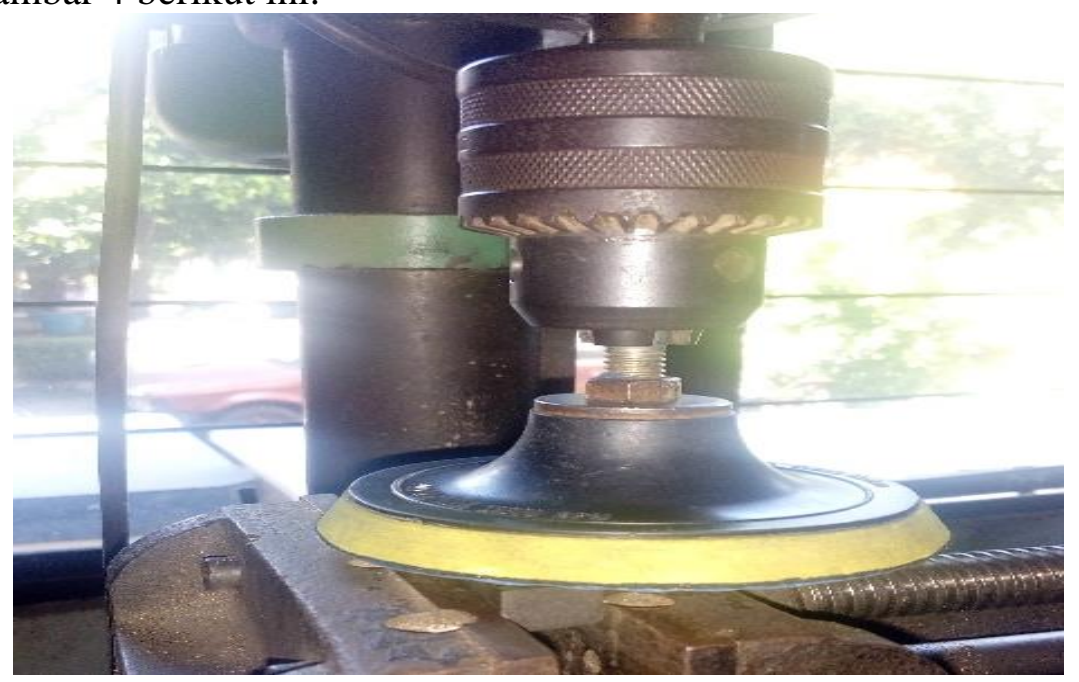

Gambar 4. Proses pengujian laju keausan 
Jurnal Teknologi, Tahun 2019, Volume 6, Edisi 2

\section{ANALISA DAN PEMBAHASAN}

\section{a. Menentukan beban pengujian.}

Beban tekan pada proses pengujian akan mempengaruhi laju keausan pada spesimen. Berdasarkan data yang ada massa trolley wire sebesar $8,9 \mathrm{~kg} / \mathrm{m}^{3}$, dengan diameter $100 \mathrm{~mm}$ dan panjang spesimen $14 \mathrm{~mm}$.

$$
\begin{aligned}
W & =8,9 \cdot 10^{3} \frac{\mathrm{kg}}{\mathrm{m}^{3}}(\pi \cdot 6,12 \mathrm{~mm}) \cdot 14 \mathrm{~mm} \\
& =144661241,89 \frac{\mathrm{kg}}{\mathrm{m}^{3}} \mathrm{~mm}^{3} \\
& =14661241,89 \cdot 10^{-9} \frac{\mathrm{kg}}{\mathrm{m}^{3}} \mathrm{~m}^{3} \\
& =0,01466 \mathrm{~kg} \\
F & =0,01466 \mathrm{KG} \cdot 9,8 \frac{\mathrm{m}}{\mathrm{s}^{2}} \\
& =0,143 \mathrm{~N}
\end{aligned}
$$

Dari hasil perhitungan diatas, beban tekan yang digunakan pada proses pengujian keausan adalah sebesar $0,143 \mathrm{~N}$.

\section{b. Pengujian kekerasan spesimen.}

\begin{tabular}{|c|c|c|c|c|c|c|c|}
\hline \multirow{2}{*}{ Benda Uji } & \multirow{2}{*}{$\begin{array}{c}\text { Beban } \\
\text { (kgf) }\end{array}$} & \multicolumn{5}{|c|}{ Hasil } & \multirow{2}{*}{$\begin{array}{c}\text { Nilai } \\
\text { Kekerasan } \\
\text { HRB }\end{array}$} \\
\hline & & $\begin{array}{c}\text { Titik } \\
1 \\
\end{array}$ & $\begin{array}{c}\text { Titik } \\
2 \\
\end{array}$ & $\begin{array}{c}\text { Titik } \\
3 \\
\end{array}$ & $\begin{array}{c}\text { Titik } \\
4 \\
\end{array}$ & $\begin{array}{c}\text { Titik } \\
5 \\
\end{array}$ & \\
\hline Trolley Wire $\mathrm{Cu}$ & 100 & 42,0 & 42,5 & 42,0 & 42,0 & 41,6 & $42,02 \pm 0,26$ \\
\hline Contact Strip $\mathrm{Cu}$ & 100 & 39,5 & 40,5 & 41 & 41,7 & 41,1 & $40,80 \pm 0,73$ \\
\hline Contact strip C & 100 & 39,2 & 38,4 & 38,8 & 39,4 & 37,6 & $38,68 \pm 0,64$ \\
\hline
\end{tabular}

Data pengujian kekerasan pada trolley wire dan contact strip dilakukan dengan menggunakan alat uji kekerasan type rockweel model HR-150 A dan 5 titik pengujian pada beban $100 \mathrm{kgf}$ dan menggunakan indentor type ball 1/16". Tabel 1 merupakan data hasil pengujian menggunakan alat uji kekerasan rockwell.

Tabel 1. Hasil Pengujian Kekerasan

Dari hasil uji kekerasan pada trolly wire dan contact strip dapat dilihat bahwa tingkat kekerasan tertinggi pada pengujian terdapat pada trolley wire dengan tingkat kekerasan sebesar 42,02 ${ }^{ \pm 0,26}$ HRB. Dan tingkat kekerasan pada contact strip dengan material Cu lebih rendah dibandingkan dengan nilai kekerasan pada trolley wire yaitu sebesar $40,80^{ \pm 0,73} \mathrm{HRB}$. Sedangkan tingkat kekerasan terendah sebesar 38,7 ${ }^{ \pm 0,64} \mathrm{HRB}$ terdapat pada contact strip dengan material $\mathrm{C}$. Tinkat kekerasan pada trolley wire dan contact strip dengan material $\mathrm{C}$ dan $\mathrm{Cu}$ berdasarkan hasil pengujian kekerasan dengan menggunakan rockwell hardness dapat dilihat pada Gambar 5. 
Jurnal Teknologi, Tahun 2019, Volume 6, Edisi 2

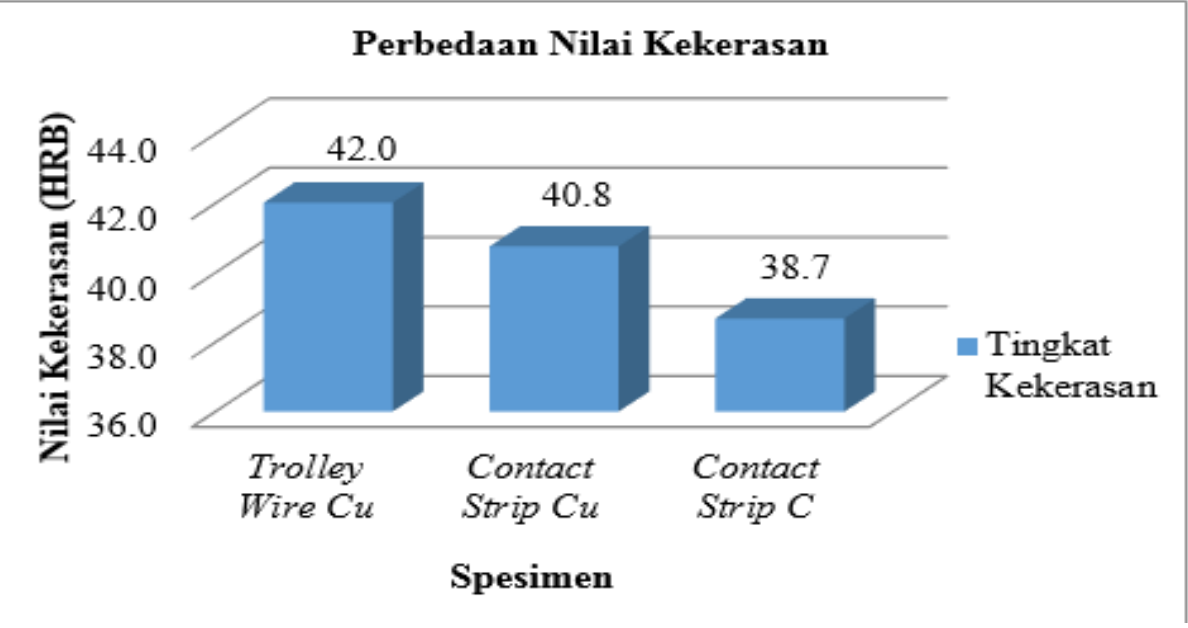

Gambar 5. Diagram balok perbedaan nilai kekerasan pada trolley wire, contact strip C, dan contact strip $\mathrm{Cu}$

\section{a. Hasil perhitungan laju keausan contact strip $\mathbf{C u}$.}

Pengujian laju keausan pada contact strip Cu dilakukan dengan 4 varian kecepatan yaitu $500 \mathrm{rpm}, 900 \mathrm{rpm}, 1250 \mathrm{rpm}$, dan $2100 \mathrm{rpm}$, serta 5 varian waktu yaitu 1 menit, 2 menit, 3 menit, 4 menit dan 5 menit, kemudian waktu dari setiap pengujian dijumlahkan menjadi 15 menit. Pada proses pengujian laju keausan beban yang digunakan adalah beban konstan yaitu 0,143 N. Hasil pengujian laju keausan pada contact strip Cu dapat dilihat pada Tabel 2.

Contoh perhitungan laju keausan :

Contact strip $\mathrm{Cu}$ setelah mangalami proses pengujian laju keausan dengan beban $0,143 \mathrm{~N}$, total waktu proses 15 menit pada putaran $500 \mathrm{rpm}$, dan berat material yang hilang $0,017 \mathrm{~g}$ dengan massa jenis contact strip material $\mathrm{Cu} 0,0089 \mathrm{~g} / \mathrm{mm}^{3}$.

Penyelesaian :

$$
\begin{aligned}
\Delta m & =8,741 \mathrm{~g}-8,724 \mathrm{~g}=0,017 \mathrm{~g} \\
\Delta V & =\frac{0,017 \mathrm{~g}}{0,0089 \mathrm{~g} / \mathrm{mm}^{3}}=1,91 \mathrm{~mm}^{3} \\
L & =2 . \pi \cdot r \\
& =2.3,14 \cdot 50 \mathrm{~mm} \\
& =0,314 \mathrm{~m}
\end{aligned}
$$

Jarak tempuh untuk kecepatan 500 rpm dengan total waktu 15 menit:

$$
\begin{aligned}
\boldsymbol{L} & =0,314.500 .15 \\
& =2355 \mathrm{~m} \\
K & =\frac{1,910 \mathrm{~mm}^{3}}{0,143 \mathrm{~N} .2355 \mathrm{~m}} \\
& =0,0056 \mathrm{~mm}^{3} / \mathrm{Nm}
\end{aligned}
$$


Tabel 2. Hasil Perhitungan Volume Keausan Pada Contact Strip Cu

\begin{tabular}{|c|c|c|c|c|c|c|c|c|c|}
\hline 월 & 貝 & $\sum_{\text {出 }}$ & 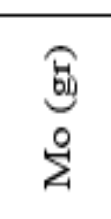 & 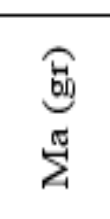 & $\underset{H}{\widehat{\Xi}}$ & 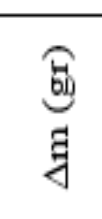 & 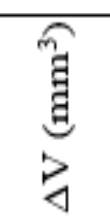 & 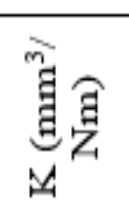 & 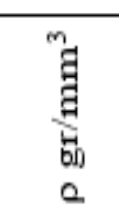 \\
\hline 500 & 15 & 0,143 & 8,741 & 8,724 & 2355 & 0,017 & 1,910 & 0,0056 & 0,0089 \\
\hline 900 & 15 & 0,143 & 8,724 & 8,700 & 4239 & 0,024 & 2,697 & 0,0044 & 0,0089 \\
\hline 15 & 15 & 0,143 & 8,700 & 8,673 & 5888 & 0,027 & 3,034 & 0,0036 & 0,0089 \\
\hline 0 & 15 & 0,143 & 8,673 & 8,644 & 9891 & 0,029 & 3,258 & 0,0023 & 0,0089 \\
\hline
\end{tabular}

Dari data yang ada, dapat dianalisa berapa nilai volume keausan yang menunjukkan besarnya volume aus atau bagian yang terkikis setiap satu satuan gaya dan jarak. Besar kecepatan suatu material yang bergerak dan mengalami kontak mempengaruhi laju keausan. Berikut grafik hubungan kecepatan dengan specific wear rate dapat dilihat pada Gambar 6.

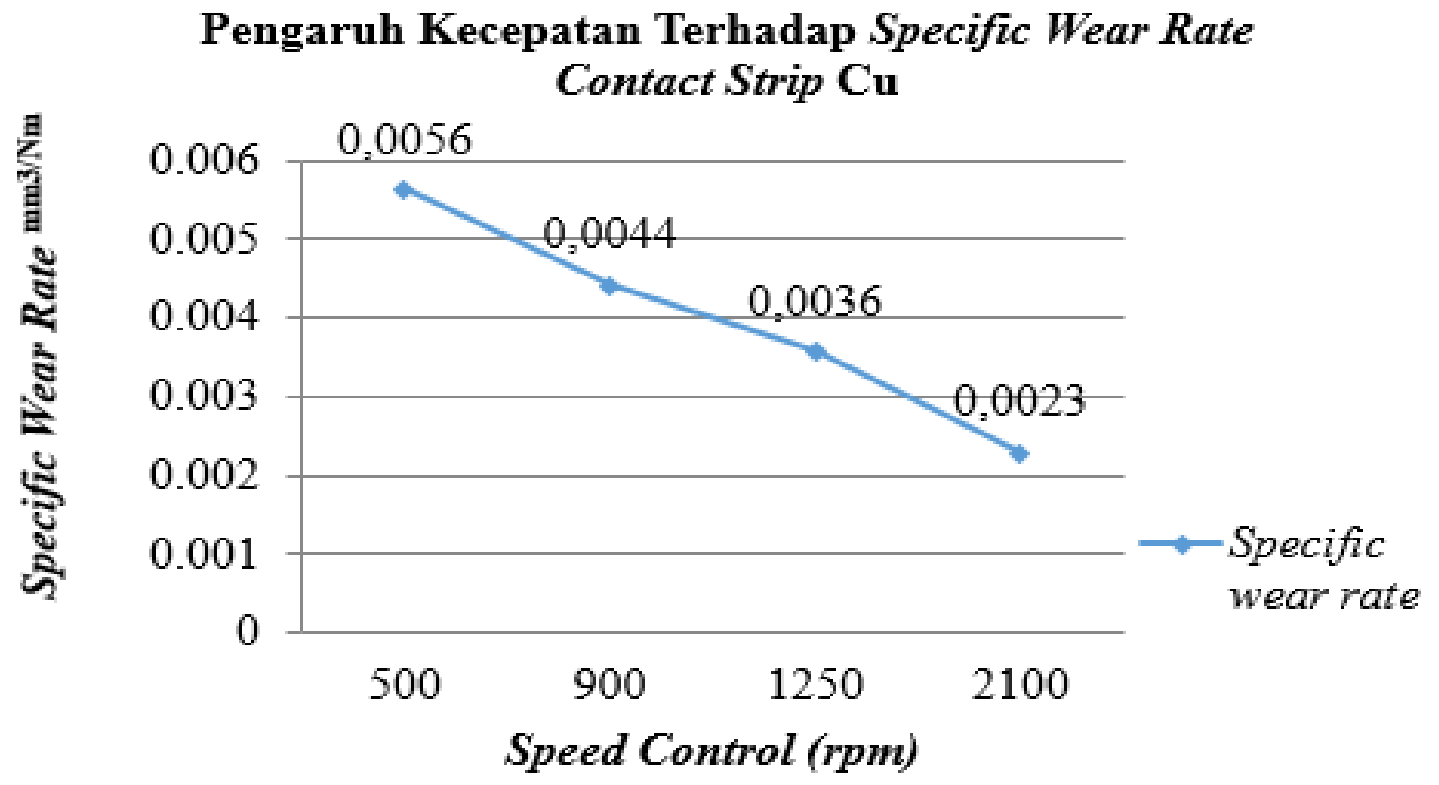

Gambar 6. Grafik hubungan wear rate contact strip $\mathrm{Cu}$ terhadap speed control (rpm)

Pada Gambar 6 di atas dapat dilihat bahwa nilai wear rate terlihat berbanding lurus dengan kecepatan, semakin besar kecepatan yang diberikan, semakin turun pula laju keausan material. Perubahan grafik wear rate terlihat linier. Dimulai dari kecepatan $500 \mathrm{rpm}$ hingga kecepatan $2100 \mathrm{rpm}$ tren grafik selalu turun. Pada kecepatan $500 \mathrm{rpm}$ nilai wear rate-nya adalah $0,0056 \mathrm{~mm}^{3} / \mathrm{Nm}$, pada kecepatan $900 \mathrm{rpm}$ nilai wear rate-nya berkurang kembali menjadi $0,0044 \mathrm{~mm}^{3} / \mathrm{Nm}$, pada kecepatan $1250 \mathrm{rpm}$ wear rate-nya berkurang lagi menjadi $0,0036 \mathrm{~mm}^{3} / \mathrm{Nm}$ dan semakin rendah pada kecepatan $2100 \mathrm{rpm}$ yaitu $0,0023 \mathrm{~mm}^{3} / \mathrm{Nm}$.

Secara teoritis, nilai wear rate akan semakin besar dengan semakin besarnya nilai kecepatan yang diberikan, namun tidak pada contact strip $\mathrm{Cu}$ ini kecenderungan saat kecepatan pertama menurun secara signifikan kecil oleh mekanisme abrasif. Pada pengujian kedua dan ketiga sampai dengan keempat contact strip $\mathrm{Cu}$ diuji dengan kecepatan yang lebih tinggi akan lebih cepat mengalami peningkatan temperatur yang semakin memperkeras 
permukaannya sehingga gerusan yang terjadi relatif lebih kecil. Semakin tinggi speed control pada saat pengujian semakin panjang pula jarak tempuh yang dicapai. Peningkatan kecepatan pada pengujian juga berpengaruh terhadap meningkatnya temperatur pada kertas abrasif, sehingga permukaan pada kertas abrasif semakin halus yang mengakibatnya gerusan pada contact strip $\mathrm{Cu}$ semakin kecil.

\section{b. Hasil perhitungan laju keausan contact strip $\mathbf{C}$.}

Hasil pengujian laju keausan pada contact strip C dilakukan dengan 4 varian kecepatan yaitu $500 \mathrm{rpm}, 900 \mathrm{rpm}, 1250 \mathrm{rpm}$, dan $2100 \mathrm{rpm}$, serta 5 varian waktu yaitu 1 menit, 2 menit, 3 menit, 4 menit dan 5 menit, kemudian waktu dari setiap pengujian dijumlahkan menjadi 15 menit. Pada proses pengujian laju keausan beban yang digunakan adalah beban konstan yaitu $0,143 \mathrm{~N}$. Dan hasil dari pengujian yang dilakukan pada contact strip C dapat dilihat pada Tabel 3.

Tabel 3. Hasil Perhitungan Volume Keausan Pada Contact Strip C

\begin{tabular}{|c|c|c|c|c|c|c|c|c|c|}
\hline 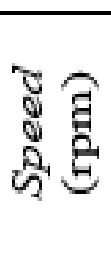 & 斯 & 己 & 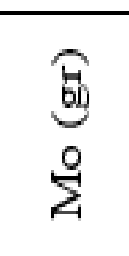 & $\begin{array}{l}\text { 鸪 } \\
\text { 劳 }\end{array}$ & $\begin{array}{l}\text { ఏ્త } \\
\mapsto\end{array}$ & 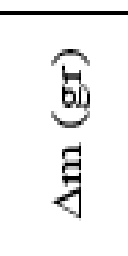 & 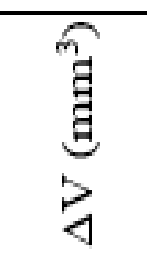 & 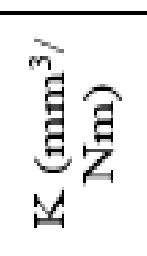 & 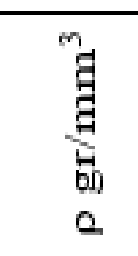 \\
\hline 500 & 15 & 0,149 & 4,793 & 4,782 & 2355 & 0,011 & 5,000 & 0,0147 & 0,0022 \\
\hline 900 & 15 & 0,143 & 4,782 & 4,760 & 4239 & 0,022 & 10,000 & 0,0164 & 0,0022 \\
\hline 1250 & 15 & 0,143 & 4,760 & 4,728 & 5888 & 0,032 & 14,545 & 0,0172 & 0,0022 \\
\hline 2100 & 15 & 0,143 & 4,728 & 4,684 & 9891 & 0,044 & 20,000 & 0,0140 & 0,0022 \\
\hline
\end{tabular}

Dari data yang ada, dapat dianalisa berapa nilai wear rate yang menunjukkan besarnya wear rate atau bagian yang terkikis setiap satu satuan gaya dan jarak. Besar kecepatan suatu material yang bergerak dan mengalami kontak mempengaruhi laju keausan. Berikut grafik hubungan kecepatan dengan volume keausan dapat dilihat pada Gambar 7. 


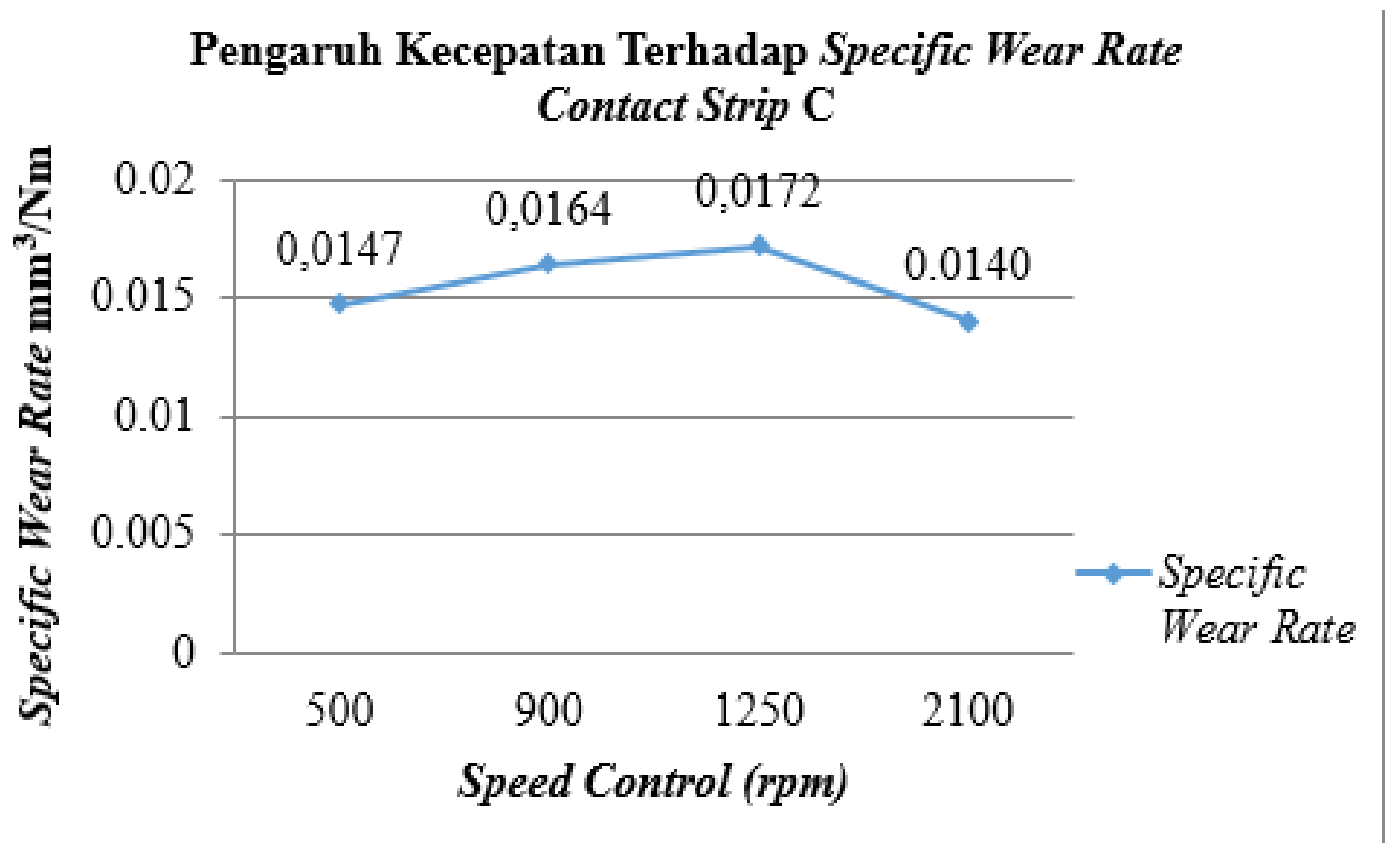

Gambar 7. Grafik hubungan wear rate contact strip C terhadap speed control (rpm)

Pada Gambar 7 secara literatur, dapat dijelaskan bahwa besarnya nilai wear rate semakin meningkat seiring bertambahnya speed control. Dimulai dari kecepatan $500 \mathrm{rpm}$ hingga kecepatan $1250 \mathrm{rpm}$ tren grafik selalu naik. Pada kecepatan $500 \mathrm{rpm}$ nilai wear rate-nya adalah $0,0147 \mathrm{~mm}^{3} / \mathrm{Nm}$, pada kecepatan $900 \mathrm{rpm}$ nilai wear rate-nya bertambah kembali menjadi $0,0164 \mathrm{~mm}^{3} / \mathrm{Nm}$, pada kecepatan $1250 \mathrm{rpm}$ wear rate-nya bertambah lagi menjadi $0,0172 \mathrm{~mm}^{3} / \mathrm{Nm}$. Namun pada kecepatan $2100 \mathrm{rpm}$ tren grafik menurun yaitu 0,0140 $\mathrm{mm}^{3} / \mathrm{Nm}$. Hal ini dikarenakan contact strip $\mathrm{C}$ mengalami peningkatan temperatur yang semakin memperkeras permukaanya sehingga gerusan yang terjadi relatif lebih kecil. Meningkatnya kecepatan pada proses pengujian berpengaruh pula pada kertas abrasif, sehingga permukaan kertas abrasif mengalami peningkatan temperatur yang mengakibatkan permukaan kertas abrasif menjadi relatif lebih halus.

\section{c. Perbandingan volume aus terhadap variasi kecepatan pada contact strip $\mathrm{Cu}$ dan contact strip C}

Dari data yang diperoleh, dapat dianalisa perbandingan nilai volume keausan terhadap variasi kecepatan. Besarnya volume keausan atau bagian yang terkikis antara contact strip material karbon $(\mathrm{C})$ dan contact strip material tembaga $(\mathrm{Cu})$. Besar kecepatan suatu material yang bergerak dan mengalami kontak mempengaruhi volume keausan. Variasi kecepatan pada proses pengujian berpengaruh terhadap nilai volume keausan pada suatu material. Hal itu bisa dilihat pada meningkatnya nilai volume keausan pada setiap variasi kecepatan. Gambar 8 merupakan perbandingan nilai volume keausan antara material tembaga $(\mathrm{Cu})$ dan karbon (C). 


\section{Volume - Variasi Kecepatan}

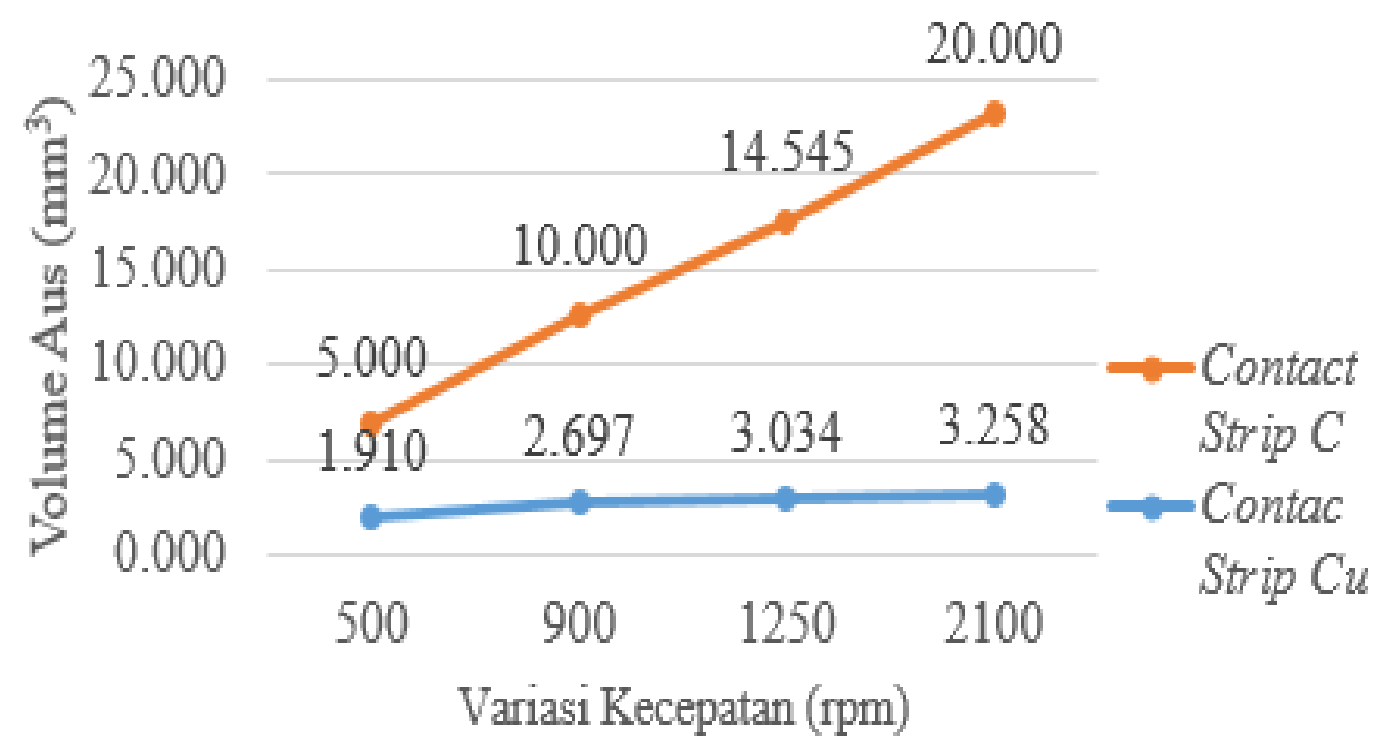

Gambar 8. Grafik perbandingan volume keausan terhadap variasi

Dari grafik di atas terlihat bahwa perbandingan volume keausan ditampilkan dalam urutan terkecil hingga terbesar terhadap variasi pengujian. Volume keausan pada pengujian contact strip $\mathrm{Cu}$ dengan beban konstan pada variasi kecepatan maksimum sebesar $2100 \mathrm{rpm}$ adalah paling rendah dibandingkan volume keausan dari variasi kecepatan maksimum sebesar 2100 rpm pada beban konstan contact strip $\mathrm{C}$. Hal ini berarti bahwa contact strip $\mathrm{Cu}$ lebih baik dan lebih tahan terhadap aus dibandingkan contact strip $\mathrm{C}$.

\section{d. Analisa struktur permukaan contact strip Cu sebelum dan sesudah pengujian}

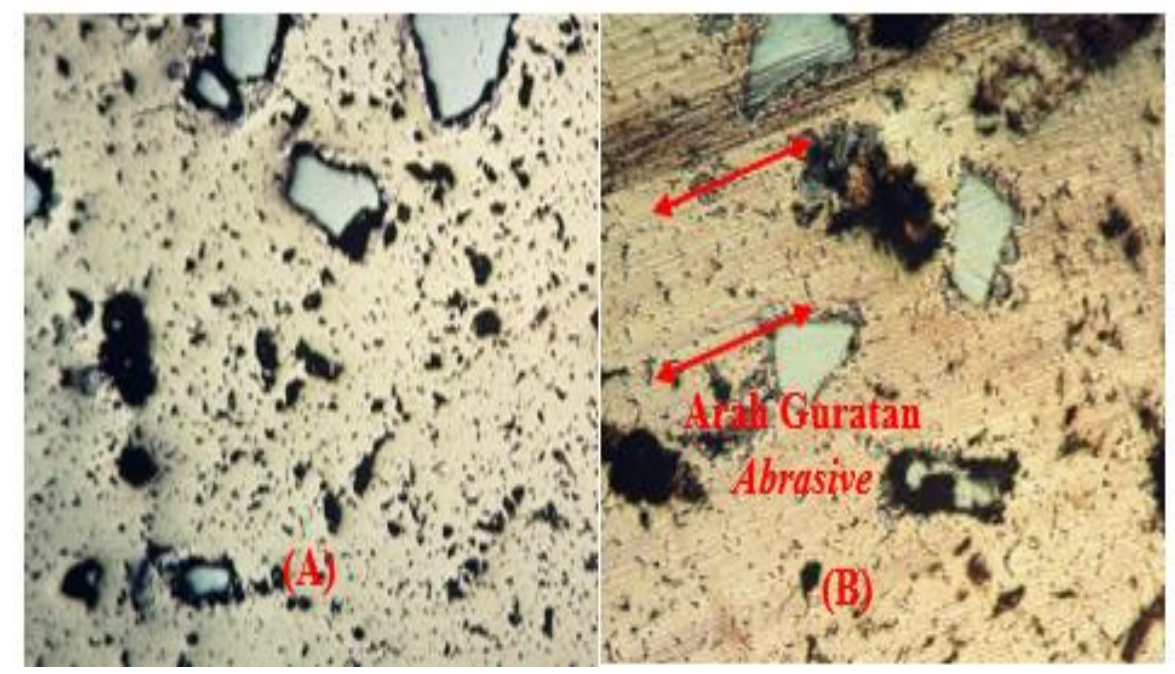

Gambar 9. Foto mikro contact strip $\mathrm{Cu}$ pada pembesaran 200x, gambar (A) contact strip $\mathrm{Cu}$ sebelum pengujian, gambar (B) contact strip $\mathrm{Cu}$ sesudah pengujian.

Pada foto mikro di atas terlihat ada perbedaan profil permukaan pada saat sebelum dilakukan pengujian Gambar 9(A) dengan setelah pengujian Gambar 9(B). Terlihat ada beberapa bagian permukaan benda uji terkelupas setelah dilakukan pengujian. 
Pada Gambar 9(B) terlihat foto contact strip $\mathrm{Cu}$ dengan pembebanan 0,143 N, kecepatan putara 500, 900, 1250 dan $2100 \mathrm{rpm}$, dalam waktu 1, 2, 3, 4, dan 5 menit. Setelah dilakukan pengujian bahwa keausan yang terjadi diakibatkan oleh mekanisme keausan abrasive yang ditunjukan adanya guratan - guratan lurus pada contact strip $\mathrm{Cu}$.

\section{e. Analisa struktur profil permukaan contact strip $\mathrm{C}$ sebelum dan sesudah pengujian}

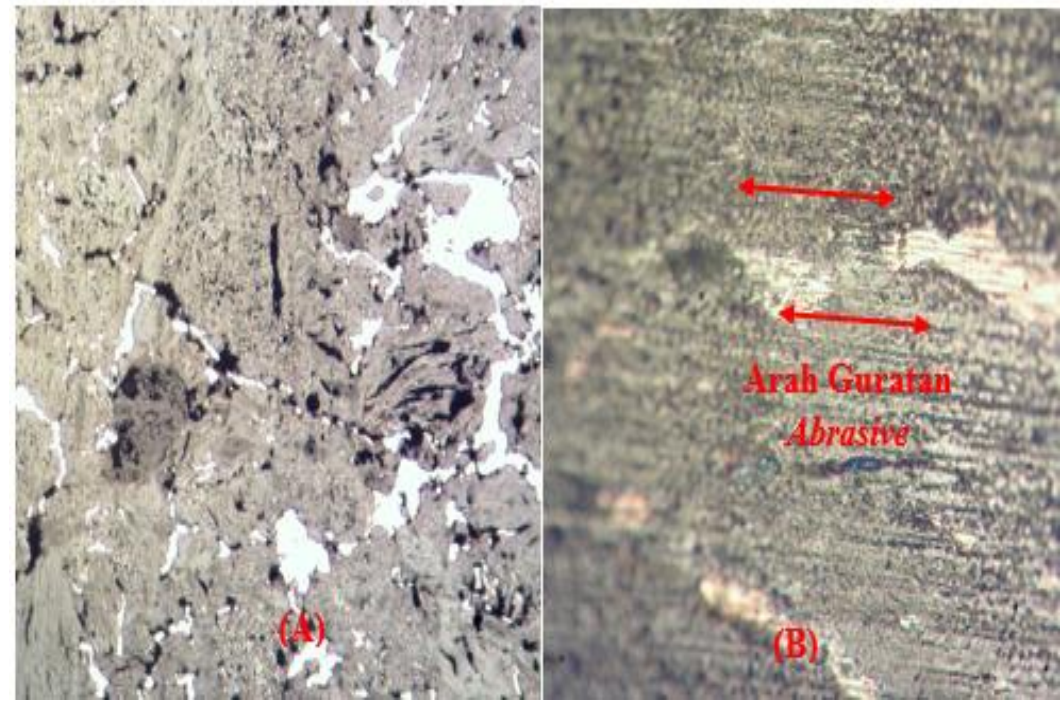

Gambar 10. Foto mikro contact strip C pada pembesaran 200x, gambar (A) contact strip $\mathrm{Cu}$ sebelum pengujian, gambar (B) contact strip $\mathrm{Cu}$ sesudah pengujian.

Pada foto mikro di atas terlihat ada perbedaan profil permukaan pada saat sebelum dilakukan pengujian pada Gambar 10(A) dan setelah pengujian Gambar 10(B). Terlihat ada beberapa bagian permukaan spesimen yang tergores setelah dilakukan pengujian. Struktur mikro material setelah pengujian terlihat lebih bergelombang dengan menunjukkan alur garis keausan arah horizontal dari pada struktur material sebelum pengujian.

Pada gambar 10(B) terlihat terjadi murni mekanisme keausan adhesive yang ditunjukkan adanya material yang terkelupas karena tergeser oleh tekanan pembebanan yang berosilasi dan tergeser oleh kertas abrasive yang mengalami kontak langsung dengan contact strip pada saat proses pengujian.

\section{KESIMPULAN}

Nilai kekerasan antara trolley wire, contact strip tembaga $(\mathrm{Cu})$ dan contact strip karbon (C) setelah mengalami proses uji kekerasan menggunakan alat uji kekerasan rockwell type HR-150 pada lima titik dengan beban $100 \mathrm{kgf}$ dan menggunakan indentor type ball 1/16", yaitu tingkat kekerasan tertinggi terdapat pada trolley wire dengan tingkat kekerasan $42,0^{ \pm 0,26}$ $\mathrm{HRB}$, diikuti tingkat kekerasan ke dua terdapat pada contact strip tembaga $(\mathrm{Cu})$ dengan tingkat kekerasan $40,8^{ \pm 0,73} \mathrm{HRB}$, sedangkan tingkat kekerasan ke tiga terdapat pada contact strip $\mathrm{C}$ dengan tingkat kekerasan $38,7^{ \pm 0,64} \mathrm{HRB}$. Contact strip tembaga $(\mathrm{Cu})$ mengalami keausan sebesar $0,00398 \mathrm{~mm}^{3} / \mathrm{Nm}$ selama proses pengujin, sedangkan pada contact strip karbon (C) mengalami keausan sebesar $0,01558 \mathrm{~mm}^{3} / \mathrm{Nm}$ selama proses pengujian. Kekasaran permukaan pada material akan mempengaruhi laju keausan pada material paduannya, semakin kasar permukaan akan mempercepat gerusan pada material paduan, sehingga laju keausan semakin tinggi. Selain kekasaran permukaan, kekerasan suatu material juga sangat berpengaruh terhadap laju keausan, semakin keras suatu material maka ketahanan 
Jurnal Teknologi, Tahun 2019, Volume 6, Edisi 2

ausnya akan semakin tinggi. Nilai laju keausan pada contact strip karbon (C) lebih rendah dibandingkan dengan nilai laju keausan pada contact strip tembaga $(\mathrm{Cu})$.

\section{DAFTAR PUSTAKA}

[1]Eskaridho Gultom dan Yusuf Kaelani, Studi Eksperimen dan Analisa Laju Keausan Material Alternatif pada Sepatu Rem Lokomotif, JURNAL TEKNIK ITS Vol. 5, No. 2, ISSN: 2337-3539 (2301-9271 Print), Surabaya, 2016.

[2]C.T. Kwok, P.K. Wong, H.C. Man dan F.T. Cheng, Sliding Wear and Corrosion Resistance of Copper-based Overhead Catenary for Traction System, IRJ (International Journal of Rail way, Vol. 3. No.1 pp. 19-27. Korean, March 2010.

[3]Tao ding, Wenjing Xuan, Qiudong He, Hao Wu and Wei Xiong, Study on Friction and Wear Properties of Pantograph Strip/Copper Contact Wire for High-Speed Train, The Open Mechanical Engineering Journal, 8, 125-128. China 2014.

[4]GX Chen, YL Wu and RX Chen, Effect of the Staggering of a Contact Wire on Wear Behaviour of the Contact Strip with Electric Current, Journal of Robotics and Mechanical Engineering Researc, Vol. 2, Issue: 1, China, 2017.

[5]Setiyo Nugroho, Ir. Bambang Winardi, Sistem Propulsion dan Auxiliary Pada Kereta Rel Listrik (KRL) Di PT. INKA (Persero) Madiun, Makalah Seminar Kerja Praktek, Semarang, 2013.

[6]Lionginas Liudvinavičius, Stasys Dailydka, The Aspects of Catenary Maintenance of Direct Current (DC) and Alternating Current (AC), Procedia Engineering 134, 268 275, Lithuania, 2016.

[7]Nobuyuki Yokohama, Research and Development toward Wear Reduction of Current Collecting System, Interpretive article, JR EAST Technical Review-No.13.

[8]R. Bagus Suryasa Majanasastra, Analisis Sifat Mekanik Dan Struktur Mikro Hasil Proses Hydroforming Pada Material Tembaga (Cu) C84800 Dan Aluminium Al 6063, Jurnal Imiah Teknik Mesin, Vol. 4, No.2, Universitas Islam 45 Bekasi, 2016

[9]Adid A. Hermansyah, Hafid dan Kosasih, Penelitian Proses Pembuatan Konsentrat Dan Ingot Tembaga Dari Batuan Mineral $\mathrm{Cu}$ Sebagai Substitusi Impor, Metal Indonesia Vol. 33 No. 2 Hal, 83- 93, Kementrian Perindustrian Balai Besar Logam dan Mesin, Bandung, 2011.

[10] David Natanael, Analisis Kualitatif pemangganan bijih Tembaga kalkopirit dengan beberapa variasiwaktu serta Leaching dengan asam sulfat 2 molar, Sekripsi Tugas Akhir, Fakultas Teknik Universitas Indonesia, Juli 2012. 
Jurnal Teknologi, Tahun 2019, Volume 6, Edisi 2

[11] Nyoman Wendri, Ni Nyoman Ratini, Ni Wayan Sariasih, dan Hery Suyanto, Analisis Reaksi Unsur Karbo Dengan Gas Nitrogen, Oksigen, dan Hidrogen Dengan Libs, Seminar Nasional Sains dan Teknologi, Denpasar Bali, 2015.

[12] Frischa Marcheliana Wachid, Darminto, Analisis Fasa Karbon pada Proses Pemanasan Tempurung Kelapa, Jurnal Teknik Pomits, Jurnal Teknik Pomits Vol. 1, No. 1, 1-4, Surabaya, 2012.

[13] Meytij Jeanne Rampe, Konversi Arang Tempurung Kelapa Menjadi Elektroda Karbon, Chem. Prog. Vol. 8. No. 2, Manado, 2015.

[14] Muhamad Choirul Azhar, Analisa Kekasaran Permukaan Benda Kerja Dengan Variasi Jenis Material dan Pahat Potong, Skripsi Tugas Akhir, Fakultas Teknik Universitas Bengkulu, 2014.

[15] Andhi Harianto, Studi Karakterisasi Material Poros Bantalan Yang Direkondisi Dengan Proses Penambahan Baja Chrome 13\% Dengan Metode Thermal Arc Spray. Skripsi Tugas Akhir, Jakarta, 2007.

[16] Gio Saputra, Alfian Hamsi, Analisa Optimasi Pemesinan Pada Mesin Bor Breda Tipe R-35 Dengan Algoritma Genetika, Jurnal $\boldsymbol{e}$-Dinamis, Volume.9, No.1, Sumatra Utara, Juni 2014.

[17] Sri Widodo, Pengaruh Keausan Permukaan Baja 410 Akibat Implantasi Ion Cr, Prosiding SNST ke-5, Sumatra Utara, 2017.

[18] Darmanto, Muhamad Thufik Ridwan, Dan Imam Syafa'at, Analisis Keausan Alumunium Menggunakan Tribotester Pin-On-Disc Dengan Variasi Kondisi Pelumas, Semarang, 2014.

[19]ASTM G 99 - 04, Standard Test Method for Wear Testing with a Pin-on-Disk Apparatus, Copyright (C) ASTM International, 100 Barr Harbor Drive, PO Box C700, West Conshohocken, PA 19428-2959, United States. 